\title{
Analysis of Mosquito Vector and Disease Spread through them in Kannur District, Kerala, India
}

\author{
Seema Gupta*, Bhramacharini Sheela, K. Smera, R. Niveditha, S. Soparnika, \\ P. K. Kartika, A. Ashwariya, S. Arundhati, K. Abhiram and P. Rithika
}

Amrita Vidyalayam, Punnol, Thalasshery, Kerala, India

*Corresponding author

\section{A B S T R A C T}

Keywords

Mosquito, Tick, Lice, Housefly, Sandfly

\section{Article Info}

Accepted:

22 January 2021

Available Online:

10 February 2021
Mosquito born diseases are most devastating among the people around the world. It has been decades where medical professionals and researchers are trying to find a remedy to stop the pathogenicity and mortality due to these vector born diseases (VBD). In the present survey and study from Thalassery region of Kannur district of Kerala reveals three types of diseases spread by vector mosquito. The study also suggests the most infected regions with patients reporting with these diseases. Also, emphasis is to trace the seasons of infection along with the age group and gender being affected more. Along with this the varieties of mosquito available at various regions are trapped and morphologically analyzed to understand the diversity of these vectors.

\section{Introduction}

It has been a century wherein humans are trying to unfold the mystery of vector born diseases. Among various carriers of disease causing pathogens, insects plays major role. Among various diseases caused in humans, 17 $\%$ infections are through vectors (Ben Nelson $\mathrm{S}$, et al., 2017). Insects including mosquito, tick, lice, housefly, sandfly, etc. are some of the major vectors to spread fatal diseases in humans and other mammals. As vector born diseases is a major problem around world,
World health organisation (WHO) brought this issue into focus during world health day of 2014 (Geneva- World Health Organization,2014).Among the present insect pest, mosquitoes spread many diseases such as dengu, malaria, yellow fever, lymphatic filariasis, chikungunya, etc., in people of India and other parts of world. They are one of the most dangerous vector as they have very adaptable lifecycle which enables tolerance for insecticides. Due to failure in controlling these dreadful vector and recurrence of fatal diseases upto million people die including 
more of children (Caraballo et al., 2014). At certain point Chikungunya was nearly disappered from India, but it re-emerged from 2005 (Mourya et al., 2001). Thus, the present study enables us to screen the mosquito species and disease caused by them in Kannur district of Kerala. As the climate and more of water bodies provides a favourable condition for these vectors to grow and transmit the disease causing pathogen in humans.

\section{Materials and methods}

\section{Site of survey}

The study through survey is conducted at various regions of Thalassery, Kannur, Kerala. This region lies $11^{\circ} 45^{\prime} 2.24^{\prime \prime} \mathrm{N} 75^{\circ} 29^{\prime} 13.28^{\prime \prime} \mathrm{E}$, with total area of $23.96 \mathrm{~km}^{2}$ and nearly 92,558 of population count. Thalassery lies $11 \mathrm{~m}$ above sea level and has significant rainfall most months. The average annual temperature in Thalassery is $27.3^{\circ} \mathrm{C} \mid 81.2^{\circ} \mathrm{F}$. The annual rainfall is $3512 \mathrm{~mm}$.

\section{Data collection}

The information regarding mosquito born diseases was obtained by survey from various govermental and private hospitals at Thalassery. Cumulative data for 4 years which includes 2017 to 2020 records is considered and analized to understand the pathogenicity and types of vectors involved.

\section{Result and Discussion}

\section{Mosquito surveillance}

Samples of mosquito is collected and studies from various regions of Thalassery including Balathil, Edelpedika, Nambyarpedika, Peringathur and Vadiyapedika. Collection is done during evening hours by trapping the insect through mosquito net and then was placed in an air tight container for few hours.
The dead insect is used to spread and photography through mobile (VivoV19, Vivo V9, I Phone 8 and Redmi note 6 pro) for documenting and further study of the same. The samples of mosquito is identified online through publications and research articles by morphological analysis (Pictorial keys for the identification of mosquitoes, Diptera: Culicidae associated with Dengue Virus Transmission, 2004; keys to the medically important mosquito species). The different types of mosquito traced in the localities are Culex pipiens, Aedes aegypti, Culex quinquefasciatus and Anopheles stephensi. Among which mosquitoes from Culex family were observed more in population (Figure 1).

\section{Pathogenicity of mosquito born diseases}

The data for mosquito born diseases are collected from year 2017 till 2020 through survey from various regions including governmental and non-governmental sources.

According to this pathogenicity of various vector borne diseases specifically involving mosquito are studied for most occuring disease along with age and gender based ratio of infection. Malingnant tertain malaria (MT Malaria) caused by $P$. falciparum and Benign tertain malaria (BT Malaria) caused by P.vivax are the two prominant types of malaria identified in the individuals of Thalassery region.

Similar work has been done by P.G Shute in year 1946 on latency and long-term relapses in Benign Tertian malaria. Along with these two types of malaria, people are also detected with Dengue in large scale. The data in the table 1 and graph 1 reflects the pathogenicity of Flavivirus causing dengue more drastic than patients with malaria. Gender and age wise records states more infection diagnosed in female than in male patients. 
Table.1 Data for various types of diseases caused by mosquito vector during year 2017-2020

\begin{tabular}{|l|c|c|c|c|c|}
\hline \multirow{2}{*}{ Sr.no. } & Type of Infection & \multicolumn{4}{|c|}{ Year per infected indivdual } \\
\cline { 3 - 6 } & & $\mathbf{2 0 1 7}$ & $\mathbf{2 0 1 8}$ & $\mathbf{2 0 1 9}$ & $\mathbf{2 0 2 0}$ \\
\hline 1. & $\begin{array}{c}\text { MT Malaria } \\
\text { (P.falciparum) }\end{array}$ & 44 & 58 & 61 & 59 \\
\hline 2. & $\begin{array}{c}\text { BT Malaria } \\
\text { (P.vivax) }\end{array}$ & 36 & 21 & 27 & 23 \\
\hline 3. & Dengue & 357 & 213 & 425 & 310 \\
\hline 4. & Total patients & 437 & 323 & 545 & 429 \\
\hline
\end{tabular}

Table.2 Comparative data for various vector born diseases in an individual with age group and gender specification

\begin{tabular}{|c|c|c|c|c|c|c|c|c|c|c|c|c|c|c|}
\hline \multirow{3}{*}{$\begin{array}{l}\text { Sr. } \\
\text { No. }\end{array}$} & \multirow{3}{*}{\multicolumn{2}{|c|}{ Study area }} & \multicolumn{12}{|c|}{ Yearly data for mosquito vector born pathogenicity } \\
\hline & & & \multicolumn{4}{|c|}{$\begin{array}{l}\text { MT Malaria } \\
\text { (P.falciparum) }\end{array}$} & \multicolumn{4}{|c|}{$\begin{array}{l}\text { BT Malaria } \\
\text { (P.vivax) }\end{array}$} & \multicolumn{4}{|c|}{$\begin{array}{c}\text { Dengue } \\
\text { (Flavivirus) }\end{array}$} \\
\hline & & & 2017 & 2018 & 2019 & 2020 & 2017 & 2018 & 2019 & 2020 & 2017 & 2018 & 2019 & 2020 \\
\hline 1. & $\begin{array}{r}\text { Inf } \\
\text { indi }\end{array}$ & $\begin{array}{l}\text { cted } \\
\text { iduals }\end{array}$ & 44 & 58 & 61 & 59 & 36 & 21 & 27 & 23 & 357 & 213 & 425 & 310 \\
\hline \multirow[t]{2}{*}{2.} & Gender & Male & 21 & 26 & 25 & 31 & 19 & 08 & 11 & 16 & 113 & 98 & 215 & 84 \\
\hline & & Female & 23 & 32 & 36 & 28 & 17 & 13 & 16 & 07 & 244 & 115 & 210 & 226 \\
\hline \multirow[t]{3}{*}{3.} & \multirow{3}{*}{$\begin{array}{l}\text { Age } \\
\text { group }\end{array}$} & Children & 04 & 06 & 13 & 10 & 05 & 09 & 04 & 05 & 23 & 19 & 27 & 19 \\
\hline & & Adults & 22 & 33 & 39 & 32 & 19 & 08 & 15 & 10 & 293 & 158 & 330 & 179 \\
\hline & & Aged & 18 & 19 & 09 & 17 & 12 & 04 & 08 & 08 & 41 & 36 & 68 & 112 \\
\hline
\end{tabular}

Graph.1 Representation of data for disease caused due to mosquito vector during 2017-2020

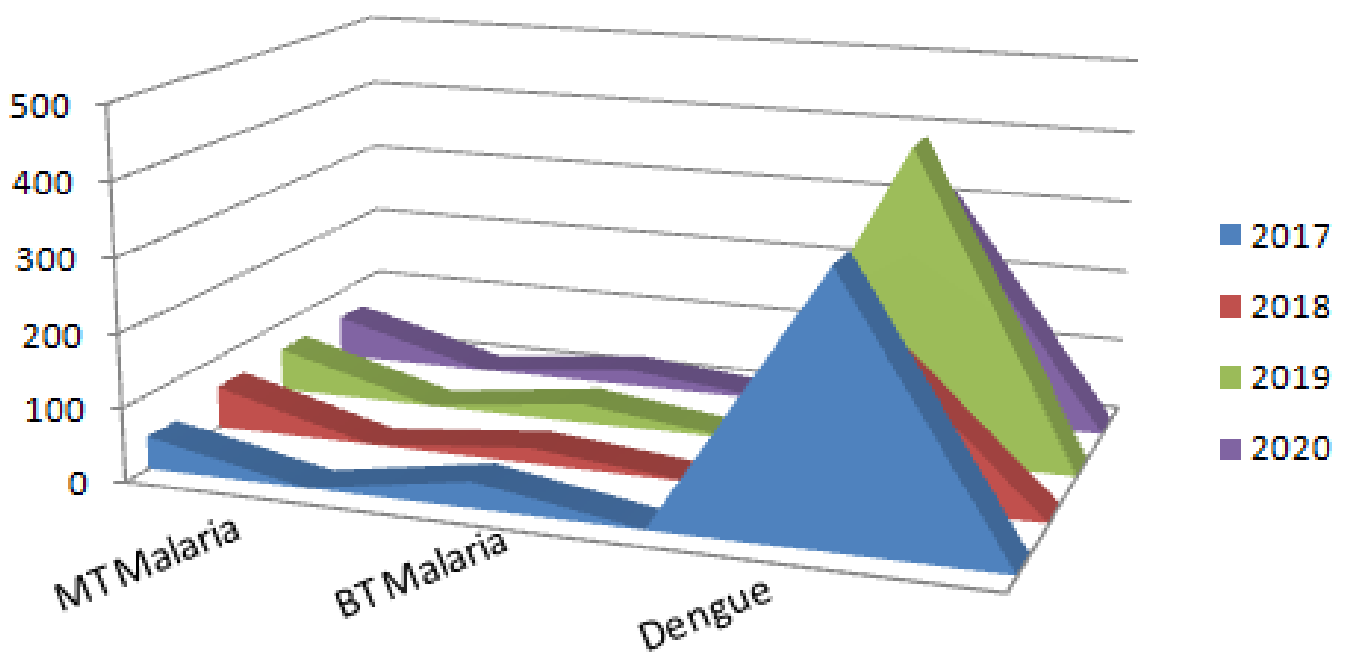


Fig.1 Different types of mosquito vectors traced from regions of Thalassery.

\section{Culex pipiens}

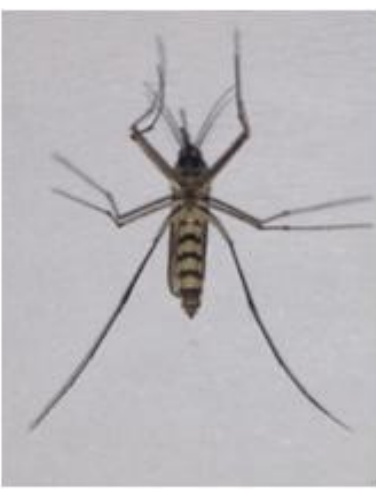

Culex quinquefasciatus

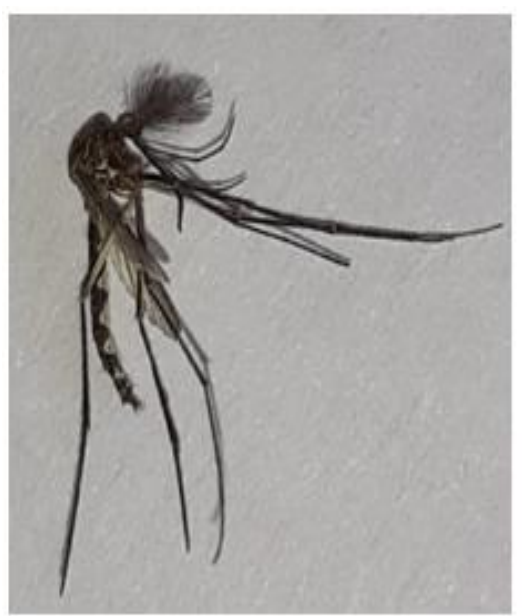

Also, malaria and dengue infections are more in adults followed by old aged people and children. M. Emmanuel Bhaskar in 2010 through his studies on dengue haemorrhagic fever among adults from Chennai, south India have also observed that adults are more infected than children and old aged people. According to the reporting date of the patients, it is evident that pathogenicity of malarial parasite is more during march to may month of the year (Table 2). Whereas, Dengu is observed more into individuals during January - February month and later from June to November month. This may be due to the life cycle of the vector species of mosquito carrying these pathogens. Among the various

\section{Aedes aegypti}

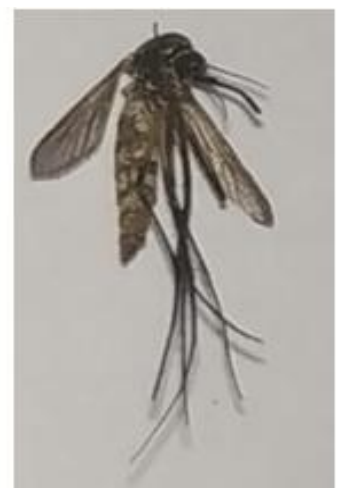

Anopheles stephensi

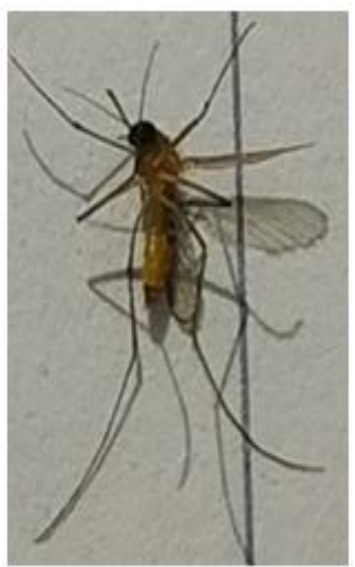

area of study from Thalassery, few region such as Panniyanoor, Poiloor, Ponniyam, Champad and Panoor shows more number of patients reporting with dengue and malaria and least number of patients are reported from Mahe.

\section{Acknowledgement}

The authors of this research paper extends gratitude towards Mata Amritanandamayi for her support and blessings for this research during this pandemic period. Also first author is thankful to Dr. Babu Ramachandran (MD Medicine) chairman of Tely hospital, Thalassery, for providing enormous help and 
guidance for yearly data collection of patients with mosquito born diseases. First author also thanks and appreciate the efforts of coauthors and students of Amrita vidyalayam, Punnol, Thalassery.

\section{References}

Ben Nelson S., G Ashok V., Nazer M., Manibalan S. (2017). Knowledge regarding mosquito borne diseases \& control measures practiced among a rural population in a southern district of Tamil Nadu, South India. Public Health Rev Int $J$ Public Health Res.;4(1):9-12.

Caraballo H, King K, 2014. Emergency department management of mosquitoborne illness- malaria, dengue, and West Nile virus. Emerg Med Pract. 2014 May; 16(5)1-23; quiz 23-4.

Keys to the medically important mosquito species. Zoogeographic Region. http://www.wrbu.org/mqID/keysMQZ oogeo.html

Leopoldo M. Rueda, 2004. Pictorial keys for the identification of mosquitoes (Diptera: Culicidae) associated with
Dengue Virus Transmission. Zootaxa 589: 1-60 (2004) ISSN 1175-5326.

M. Emmanuel Bhaskar, Swathy Moorthy, N. Senthil Kumar, and Preetam Arthur, 2010. Dengue haemorrhagic fever among adults - An observational study in Chennai, south India. Indian J Med Res.2010 Dec; 132(6): 738-740.

Mourya, D. T., Thakare, J. P., Gokhale, M. D., Powers, A. M., Hundekar, S.L., Jayku-mar, P.C., Bondre, V.P., Souche, Y.S. and Padbidri, V.S, 2001. Isolation of Chi- kungunya Virus from Aedes aegypti Mosquitoes Collected in the Town of Yawat, Pune District, Maharashtra State, India. Acta Virology,45, 305-309.

P.G Shute, 1946. Latency and long-term relapses in Benign Tertian malaria. Transactions of The Royal Society of Tropical Medicine and Hygiene, Volume 40, Issue 2, October 1946, Pages 189-200, https://doi.org/10. 1016/0035-9203(46)90056-9.

World Health Organization. A global brief on vector-borne diseases. Geneva- World Health Organization. 2014;54.

\section{How to cite this article:}

Seema Gupta, Bhramacharini Sheela, K. Smera, R. Niveditha, S. Soparnika, P. K. Kartika, A. Ashwariya, S. Arundhati, K. Abhiram and Rithika, P. 2021. Analysis of Mosquito Vector and Disease Spread through them in Kannur District, Kerala, India. Int.J.Curr.Microbiol.App.Sci. 10(02): 3128-3132. doi: https://doi.org/10.20546/ijcmas.2021.1002.342 